\title{
JONATHAN EDWARDS O NEGATYWNEJ I POZYTYWNEJ PRZYCZYNIE ZLA MORALNEGO ORAZ O RODZAJACH SKŁONNOŚCI TKWIĄCYCH W NATURZE LUDZKIEJ
}

\section{Popularna, ambiwalentna recepcja stanowiska Edwardsa i jej unifikacyjna alternatywa}

Znawcy pism Edwardsa zwykli przyjmować, że między wczesnymi, a późnymi pracami filozofa występuje radykalna zmiana poglądu w kwestii źródła zła moralnego w naturze ludzkiej. Zgodnie z powyższym stanowiskiem młody Edwards przedstawiany jest jako zwolennik p ry w a t y w n e j koncepcji neoplatońskiej (od łac. privatio - brak, pozbawienie, utrata), na gruncie której za jedyną przyczynę zepsucia natury ludzkiej (jej zła) uznaje się tak zwany brak d obra. Natomiast Edwards dojrzały miałby już twierdzić, za św. Pawłem, rzecz niejako przeciwną i zdaniem wielu stojącą w sprzeczności z wcześniejszym twierdzeniem, mianowicie: że źródło zła moralnego jest pozytywne. Innymi słowy, że w duszy człowieka istnieje odrębna skłonność, za sprawą której znajduje on przyjemność w tym, co moralnie niewłaściwe. Istnieją jednak przesłanki, by sądzić, że filozof oba te wyjaśnienia traktował poważnie na wszystkich etapach swego duchowego rozwoju jako awers i rewers jednej koncepcji. Podobne ambiwalentne podejście charakteryzowało Edwardsowskie stanowisko w kwestii predestynacji, w wypadku której również mamy do czynienia ze swego rodzaju awersem i rewersem w postaci Bożej suwerenności oraz ludzkiej wolności.

Przedstawmy owe przesłanki. Otóż w pismach z lat późniejszych nie znajdujemy u Edwardsa krytyki koncepcji braku, co byłoby rzeczą natu- 
ralną w przypadku tak radykalnej zmiany stanowiska. Jednocześnie zgodnie z jego przekonaniem, uformowanym już we wczesnej młodości, do działania może człowieka pobudzać tylko realna skłonność. Tym samym, zdaniem filozofa, niewątpliwą cechą pobudki skłaniającej człowieka do moralnego zła jest jej realność. W rzeczywistości byłoby zatem tak, że w miarę dojrzewania myśliciel przesunął akcent w wypowiedziach, a nie - że zmienił poglądy. Można by rzec, parafrazując wypowiedź Marka Valeriego ze wstępu do zbioru kazań i rozpraw Edwardsa z lat 1730-1733 (w którym ów redaktor zwracał uwagę na wyżej wspomnianą dwuaspektowość predestynacji oraz związane z tym przesuwanie akcentów z Bożej suwerenności na wolność indywidualną człowieka w ramach różnych kazań), że w kazaniach i pismach dotyczących kwestii zła Edwards podchodził do sprawy w sposób prak t y c z n y i z tego powodu jednym razem przypominał zwolennika neoplatonizmu, a innym manichejczyka w sensie historycznym, nie będąc ani jednym, ani drugim. Na czym w istocie polegało owo praktyczne podejście postaramy się wyjaśnić w części podsumowującej zagadnienie.

\section{Dwa ujęcia koncepcji prywatywnej}

Powszechnie tezę neoplatonizmu interpretuje się jako twierdzenie, że zło samo w sobie jest niebytem (aspekt istotowy) oraz że bezpośrednią, a tym samym sprawczą przyczyną zła jest niebyt rozumiany jako ontologiczne nic (aspekt przyczynowy). Twierdzi się tak, ponieważ d o b r o utożsamiane jest $\mathrm{w}$ tej koncepcji $\mathrm{z}$ istnieniem jako takim, a nie z moralnością ${ }^{2}, \mathrm{w}$ myśl Platońskiej triady: dobro = byt = prawda. To, czy dla

\footnotetext{
1 Por. J. Edwards, Sermons and Discourses, 1730-1733, Works of J. Edwards, Vol. 17, ed. M. Valeri, Yale University Press, New Haven 1999, s. 9. Jest to trzeci z sześciu wydanych dotychczas tomów kazań.

2 W koncepcji Platońskiej brak wyraźnego rozróżnienia dwóch zupełnie różnych pojęć: dobra jako bytu i dobra jako moralnego czynu. Moralność zostaje związana z Platońską koncepcją dopiero poprzez osobny aksjomat. Zgodnie z nim dobre jest to, co jest takie, jakie być powinno. Byt jest dobry, taki jaki być powinien, kiedy w pełni służy celowi, dla którego został stworzony. Mamy tu ewidentnie dwa pojęcia dobra: jako bytu i jako powinności. Podstawiwszy pod „byt” „dobro" uzyskujemy tezę: Dobro (czyt. istnienie) jest dobre takie, jakie być powinno. Jeśli celem człowieka jest realizacja moralnego dobra, powinności czy idei, to ten, kto go nie realizuje, będąc człowiekiem, jest zły i w takiej mierze, w jakiej jest zły, w takiej jest niebytem. Ten ostatni „byt”
} 
samego twórcy neoplatonizmu, Plotyna, niebyt był rzeczywiście niebytem ontologicznym, a zatem brakiem istnienia czegokolwiek, dosłownie niczym, czy też pod określeniem tym skrywała się znienawidzona przez gnostyków materia, postrzegana subiektywnie jako nic w opozycji do bytu per se, tj. idei, jest kwestią osobną. Dosłownie rozumiana teza neoplatonizmu jest w sposób oczywisty absurdalna - zarówno w aspekcie istotowym, jak i przyczynowym.

Jeśli mowa o istocie zła, wystarczy zauważyć, dla przykładu, że nieistnienie ludzi - w takim czy innym sensie złych - skłonni bylibyśmy zakwalifikować jako dobry stan rzeczy³ a więc potocznie rozumiane, jako dowolne, nie może być istotą zła. Jeżeli jednak owo nie is tnienie rozumiemy jako wybrakowanie bytów skończonych, pewną ich niedoskonałość, która może przecież polegać zarówno na niedoborze, jak i nadmiarze pewnych składnikó $\mathrm{w}^{4}$, teza przestaje być absurdalna. Trzeba jednak objaśnić, na czym polega niedoskonałość i skąd pochodzi. Z kolei $\mathrm{w}$ aspekcie przyczynowym racjonalne jest jedynie twierdzenie, że bezpośrednią przyczyną sprawczą może być tylko i wyłącznie coś realnego. Jeśli mówimy, że przyczyną istnienia jakiegoś bytu jest dosłownie n i c, znaczyć to może, po pierwsze, że - według nas - istnieje coś, co nie ma przyczyn. Takie coś po prostu jest, samoistnie, a skoro jest po prostu, to jest odwieczne, poza czasem i niejako niezależnie od dobrego Boga; mielibyśmy zatem do czynienia $\mathrm{z}$ tezą manichejską (i w związku $\mathrm{z}$ tym neoplatończyków należałoby uznać za manichejczyków - za tamtych stereotypowe przeciwieństwo). Po drugie, może znaczyć, że realne jest tylko to, co ma realną przyczynę, że zło moralne nie istnieje, że musi być tylko złudzeniem, skoro nie ma takiej przyczyny. To ostatnie stwierdzenie pro-

\footnotetext{
rozumiany jest metaforycznie, a nie dosłownie.

3 Nawet w Biblii mówi się o Judaszu ustami Jezusa: „Biada temu człowiekowi, przez którego Syn Człowieczy jest wydawany. Lepiej by dla takiego człowieka było, gdyby się nie narodził" (Mt. 26, 24, Biblia Tysiąclecia).

4 Choć jedna z ludowych mądrość głosi, że od „,przybytku głowa nie boli”, a inna, że „co dwie głowy to nie jedna", to jednak nikt przytomny nie będzie rozpaczał z tego powodu, że jego dziecko urodziło się z jedną, a nie dwoma lub trzema głowami. Stąd wniosek, że zło objawia się nie tylko jako brak, ale także jako nadmiar.
} 
wadziłoby do kwietyzmu - wykształcenia postawy biernej wobec zła na skutek negowania jego istnienia.

Oprócz powyższych istnieje jeszcze możliwość stanowiska pośredniego. Zwolennicy tego ostatniego negują substancjalność zła, a jednocześnie odrzucają tezę o jego iluzoryczności. Na zarzut, że ich przekonania są sprzeczne, odpowiadają zwykle, że choć zło samo nie jest bytem, nie jest też iluzją, gdyż zło na tym polega, że w bycie (dobrym) tkwi brak. Na podobnej zasadzie widzimy, że w prześcieradle j e st dziura. To nie iluzja. Nie można jednak mówić o dziurze w oderwaniu od tego, co jest dziurawe. Czytelnik zechce zauważyć, że to nie dziura jest w owej koncepcji złem, lecz złe jest prześcieradło oraz to, co ową dziurę powoduje. Sedno problemu tkwi jednak w tym, czy ową analogię można przełożyć na ludzkie działania, mianowicie: czy zły moralnie czyn to jedynie d zi u raw y czyn moralnie dobry, na przykład mniej korzystny? Czym innym będzie stwierdzenie, że niemoralny postępek często przynosi komuś indywidualnie lub pewnej grupie czy wspólnocie jakąś konkretną korzyść lub przyjemność rozumianą jako dobro (Edwards potwierdza, że niemoralne czyny przynoszą często znaczne korzyści lub sprawiają przyjemność tym, którzy je popełniają, tak że jedynym dla nich hamulcem może być myśl o piekielnej, nieuniknionej karze ${ }^{5}$ ), a czym innym jest stwierdzenie, że czyn jest dobry w sensie moralnym. Niekorzystne dobro moralne nie jest moralnym złem, a korzystne zło nie jest dobrem. Tak samo jak ludobójstwo, choćby to, którego dopuściła się Ukraińska Powstańcza Armia na polskich rodzinach z Wołynia i okolic, nie jest przejawem uszkodzonego bohaterstwa, choćby przynosiło oprawcom i ich wspólnotom znaczne korzyści materialne lub sprawiało im wielką radość. Uszkodzenie moralnej cnoty zmniejsza tylko poziom dobra na jego skali absolutnej, od maksimum do zera, a zatem do stanu obojętnego. Tymczasem moralne zło znajduje się na przeciwnym biegunie skali - poniżej zera. Gdy wybieramy s w oje dobro, swoją korzyść czy przyjemność, a te równoznaczne są z cudzym, niezasłużonym złem, to nie wybieramy po prostu mniejsze-

5 Por. J. Edwards, Warnings of the Future Punishment Don't Seem Real to the Wicked, w: tegoż, Sermons and Discourses 1723-1729, ed. by Kenneth P. Minkema, Works of J. Edwards, Vol. 14, Yale University Press, New Haven 1997, s. 207-208. 
go dobra moralnego - dobra pomniejszonego o zło innej osoby, ale zło moralne właśnie. Takie przedstawienie sprawy - za pomocą defektu - to sofistyka. Można jedynie powiedzieć: wybieramy swoją doraźną korzyść, wartość utylitarną lub hedoniczną, zamiast wartości perfekcyjnej czy duchowej. Innymi słowy, wybieramy to, co życiowe, co pozwala nam się s p e łn i a ć zamiast wybrać, co moralne. Jedyną właściwą opozycją dla wyboru moralnego jest wybór niemoralny, a nie mniej moralny. Do kwestii tej wrócimy jeszcze, omawiając zagadnienie naturalnych skłonności ludzkich, w szczególności m iło śc i wła s nej wraz z jej społecznymi przejawami.

Ustalenie tego, które z wyżej wymienionych stanowisk najbliższe jest poglądowi Edwardsa, wymaga szczegółowej analizy. Sądzimy, że zgodziłby się z tezą o s a mo istnośc i moralnego zła. Z pewnością nie był kwietystą $\mathrm{i}$ - tak jak pisaliśmy już na wstępie - odrzucał również podejście, zgodnie z którym przyczyna czegokolwiek realnego mogłaby być nierealna. Według filozofa, s k u t e c z n o ść, a zatem powodowanie skutków, jest niezbitym dowodem substancjalności tego, co skutki powoduje. Czytamy o tym:

Główną rzeczą, po której odróżniamy to, co prawdziwe i substancjalne, od tego, co jest tylko cieniem lub pozorem, jest skuteczność (it is effectual). Cień lub obraz człowieka, choćby był nie wiem jak dobrze namalowany i stanowił nie wiadomo jak żywą reprezentację i choćby był obrazem bardzo silnego człowieka, zaiste, potężnego olbrzyma i tak nie może nic zdziałać; nic za jego sprawą zajść nie może, gdyż nie jest [olbrzymem - przyp. A. Z.] prawdziwym, a jedynie cieniem czy obrazem rzeczy. A jednocześnie substancja i rzeczywistość są tym, co jest skuteczne ${ }^{6}$.

Możemy stąd wnosić, mówiąc już całkiem konkretnie, nie o braku jako takim, ale o braku dobra moralnego w naturze ludzkiej jako przyczyni e zła. Edwards nie twierdził, że jednocześnie nie ma w niej nic realnego - że nie ma w niej jednej lub większej liczby immanentnych pobudek, które w sumie składają się na skłonność do moralnie

6 Dlatego też Łaska, rozumiana jako pryncypium świętości obecne w sercu, powoduje zawsze skutki dla niej właściwe. Por. J. Edwards, Sermon Ten: Grace Tends to Holy Practice, w: tegoż, Charity and its Fruits, w: tegoż, Ethical Writings, ed. by P. Ramsey, Works of J. Edwards, Vol. 8, Yale University Press, New Haven 1989, s. 298. 
nagannych czynów. I faktycznie nigdy tak nie uważał, gdyż - podkreślmy to raz jeszcze, jako przyczyny sprawcze działań uznawał tylko i wyłącznie pobudki realne, inaczej mówiąc p o zy ty w n e, a nie brakujące, $\mathrm{n}$ e g a t y w n e. Także w traktacie Grzech pierworodny autor pisze wprost o ,pozytywnych pryncypiach grzechu”" . Stąd wniosek, iż Edwards uznawał brak dobra moralnego w duszy, jako przyczynę moralnego zła negatywną, a nie pozytywną czy sprawczą. Naturę ludzką w stricte chrześcijańskim ujęciu Edwardsa, można porównać do samochodu wyposażonego w napęd na cztery osie, w którym popsuły się hamulce. Kiedy pojazd rusza, nieuchronnie taranuje wszystko, co mu wpadnie pod koła. Należy to rozumieć tak, że gdyby w charakterze człowieka tkwiła autentyczna, pełna miłość dobra moralnego, aktywna dyspozycja (sprawny system kierowania i hamowania), to wyparłaby, unieszkodliwiła czy też zniszczyła tendencję przeciwną ${ }^{8}$. O tym, że dla Edwardsa koncepcja braku nigdy nie była wystarczająca, aby należycie tłumaczyć niemoralne uczynki, świadczą chociażby wypowiedzi, które znajdujemy w Kazaniu dziewiątym, jednym z serii kazań o miłosierdziu i jego owocach (w oryginale: Charity and Its Fruits). Edwards wyjaśnia tam, w jaki sposób duch krytykanctwa przeciwny jest chrześcijańskiemu i stwierdza: „Przyczyną jest brak chrześcijańskiej miłości wobec bliźniego i przeważanie ducha przeciwnego”. A nieco wcześniej w tym samym kazaniu zauważa: „Niektórzy kochają myśleć źle o innych, ich skłonność jest taka"9. Także w traktacie Natura prawdziwej cnoty znajdujemy paralelną do powyższych wypowiedź o następującej treści: „Cała przywara, grzech czy zło moralne polega na braku tej miłości wobec innych, albo przeciwnie, mianowicie na nienawiści czy złośliwości (malevolence)"10.

\footnotetext{
7 Por. J. Edwards, Original Sin, ed. by Clyde A. Holbrook, Works of J. Edwards, Vol. 3, Yale University Press, New Haven 1970, s. 146. Przekład stosownego cytatu z powyższego dzieła umieściłam w innym artykule poświęconym Edwardsowi. Por. A. Zalewska, Zło radykalne w naturze ludzkiej wedlug Jonathana Edwardsa, „Edukacja Filozoficzna” 2015, nr 60, s. 142-143.

8 W kwestii hamowania złej miłości własnej przez miłość moralnego dobra (Boga) por. J. Edwards, Sermon Seven: Charity Contrary to a Selfish Spirit, w: tegoż, Charity and its Fruits, dz. cyt., s. 255-257.

9 Por. tenże, Sermon Nine: Charity Contrary to a Censorious Spirit, w: tegoż, Charity and its Fruits, dz. cyt., s. 287-288.

10 Por. tenże, Chapter 5: On Natural Conscience and Moral Sense, w: tegoż, The Nature of True
} 
Powyższe cytaty wskazują na istnienie przyczyny pozytywnej moralnego zła. Zasadniczy problem, zdaniem filozofa, polegałby więc na tym, że człowiek rodzi się pozbawiony pobudki przeciwnej, rozumianej jako realna siła hamująca zło a jednocześnie pobudzająca do realizacji dobra. Istotne jest także, że ci, którym Bóg zsyła w końcu ową siłę jako zbawienną łaskę, posiadają ją w stopniu niedoskonałym - jej pełnię osiągają dopiero po sądzie ostatecznym. Jest to, naszym zdaniem, pełn i a mi $\nmid$ oś c i rozumiana raczej jako brak warunków do realizacji zła moralnego: wyzwolenie duszy ze złych motywów zewnętrznych i wewnętrznych, a nie przydanie większej łaski skutecznie hamującej złe zapędy. Świadczyłyby o tym wywody Edwardsa na temat hierarchii świętości w niebie, z jego kazań o miłosierdziu ${ }^{11}$. Hierarchia taka jest wynikiem czynników immanentnych, a nie wzmożonej łaski.

Na brak wrodzonych moralnych hamulców wskazuje fakt, że w sposób niewątpliwy Edwards wiązał obecność oc alającej łaski (saving grace), będącej łaską wiary kierującej działaniami, z aktywną dyspozycją do moralnego dobra, choć jednocześnie utrzymywał, że poszczególne osoby mające ją w przyszłości przyjąć zostały przez Boga wybrane poza czasem. (A to już łaska w innym sensie, łaska predyspozycji czy predestynacji). W Kazaniu dziesiątym pod tytułem Miłosierdzie skłania do świętej praktyki, podkreślając praktyczny wymiar łaski, pisze:

Jeśli ktokolwiek ma pojęcie łaski, jako czegoś włożonego (put into) w serce, by zostało związane i leżało nieczynne, i że jej wpływ nie zarządza człowiekiem, jako aktywną istotą, albo że zmiana serca, która zostaje uczyniona, gdy łaska zostaje wzbudzona [infused - dosł. zaparzona, wlana - przyp. A. Z.], choć w rzeczy samej naprawia serce, nie wykazuje tendencji do proporcjonalnej poprawy życia, ten ma nieprawidłowe pojęcie o niej ${ }^{12}$.

Na podstawie dwuznacznego czasownika infuse (oznaczającego zarówno parzenie, jak i nalewanie), kontekstu wypowiedzi oraz faktu uznawania przez Edwardsa predestynacji można sądzić, że autor miał tu na

Virtue, w: tegoż, Ethical Writings, dz. cyt., s. 594.

11 Por. tenże, Sermon Fifteen: Heaven is a World of Love, w: tegoż, Charity and its Fruits, dz. cyt, s. 376-379.

12 J. Edwards, Sermon Ten: Grace Tends to Holy Practice, w: tegoż, Charity and its Fruits, dz. cyt., s. 294. 
myśli skutki wzbudzenia nieaktywnej wcześniej predyspozycji, a nie stworzenie dyspozycji z niczego, bez żadnej bazy w sercu ${ }^{13}$. Dla jasności należałoby więc mówić o dwóch odmianach łaski, które łącznie gwarantują dobrą wolę, czego Edwards wprost nie czyni, podobnie jak nie uczynił tego św. Augustyn. Obie te odmiany zostają przyznane osobom wybranym na mocy predestynacji, poza czasem. Jednak pierwsza jest łaską i $\mathrm{m} m$ a $n$ e $n \mathrm{t} n$ ą dla jednostki, gdyż znajduje się w niej samej. Odnosząc się do egzegezy biblijnej przypowieści o siewcy, przedstawionej przez Edwardsa w kazaniu Profitable Hearers of the Word ${ }^{14}$ (dosłownie: Zyskujacy słuchacze Słowa), możemy powiedzieć, że reprezentuje ją grunt dobry do zasiewu - podatny na wzrost dobroci. Druga to łaska tr a n s c e n d e n t na wobec nią obdarzanego, jest nią spadające na ten grunt dobre nasienie, które w przypowieści symbolizuje Słowo Boże, a temu odpowiada wychowanie $\mathrm{w}$ chrześcijańskiej wspólnocie ${ }^{15}$. Niemniej jednak ocalająca łaska (na którą składają się obie wyżej wspomniane odmiany) nie pochodzi, zdaniem filozofa, z tego, co w człowieku naturaln e ${ }^{16}$ (konieczne do życia). Pisze o tym w kazaniach z cyklu o miłosierdziu, ale także w traktacie Grzech pierworodny. Rzecz ujmuje takimi słowy: „To, co jest dobre w chrześcijanach, żadną miarą nie znajduje się w nich naturalnie, ale jest dziełem Bożej łaski"'17.

Powyższe zdanie należy rozumieć tak, że ani łaska immanentna ani transcendentna nie działa w człowieku aktywnie od początku jego istnienia i nie jest powiedziane, że zadziałać musi, a zatem praktycznie czło-

\footnotetext{
13 Wskazuje na to także fragment wypowiedzi, w którym Edwards tłumaczy sens opozycji między pobudkami naturalnymi i duchowymi. Patrz cytat zamieszczony niżej w niniejszym tekście, s. 86.

14 Por. tamże, s. 248. Kazanie to, jak wiadomo na podstawie notatek Edwardsa, zostało wygłoszone ponownie w czerwcu 1756 roku.

15 Analizując z pozycji współczesnej zagadnienie łaski w koncepcji św. Augustyna, P. Okołowski zwraca uwagę na konieczność odróżnienia wspomnianych dwóch typów łaski. Łaskę symbolizowaną w przypowieści przez dobry grunt określa mianem „łaski warunkującej” (sprowadza się ona do posiadania dobrych genów), natomiast łaskę symbolizowaną przez nasienie nazywa „łaską kierującą". Por. tenże, Neoaugustinus, w: tegoż, Filozofia i los. Szkice tychiczne, Universitas, Kraków 2015, s. 320-321.

16 Por. tenże, Sermon Seven ..., w: tegoż, Charity and Its Fruits, dz. cyt., s. 264.

17 Por. J. Edwards, Original Sin, dz. cyt., s. 302.
} 
wiek jest jej pozbawiony. Ponadto w powyższym kontekście potwierdza się interpretacja, zgodnie z którą tezę o złu jako braku dobra rozumieć należy jako tezę o przyrodzonej wadzie natury ludzkiej, polegającej na braku skłonności hamującej moralne zło oraz skłaniającej do moralnego postępowania. Krótko: zło jest brakiem dobra znaczy, że jest brakiem łaski immanentnej bądź transcendentnej. Przy tym brak łaski nie jest „stanem posiadania zerowym”, lecz a n t y ł a s k ą. Teza ta zgadza się z prawidłowością dostrzeganą przez Edwardsa, ale także jego wielkiego poprzednika - św. Augustyna - wskazującą na asymetrię, jaka zachodzi między dobrem i złem moralnym. Asymetria ta polega na empirycznie dostrzeganym fakcie, że zła moralnego nikt nas uczyć nie musi, gdyż wypływa ono z natury człowieka spontanicznie ${ }^{18}$ (byłaby to cecha zła identyczna ze wspominaną wcześniej samoistnością $\left.{ }^{19}\right)$. W Notatniku z kontrowersjami czytamy:

Jest ewidentnym, w rzeczy samej, że awersja wobec dobroci i gwałtowne (violent) skłonności do występku (vice) realizują się i ujawniają bardzo wcześnie u wszystkich zrodzonych na tym świecie. Kto nie dostrzega w innych i nie czuł sam w sobie od najdelikatniejszego wieku, od pierwszych przebłysków (openings) racjonalnych zdolności, zanim pojawiło się jakiekolwiek miejsce na wpływ, naśladownictwo czy zwyczaj, silnej przeciwinklinacji (disinclination) i nieporuszenia (disaffection) tym, co jest duchowo dobre, w połączeniu z silnym uzależnieniem od próżności, pychy, kłamstwa, uporu, zemsty i innych rzeczy samych w sobie nieprawych (unlawful) albo w mierze dyspozycji wobec nich? Tych form zła (these evils) uczymy się sami z siebie, bez mistrza czy podżegacza (master or prompter), przeciwnie, wbrew najlepszym nauczycielom i przykładom, pod naciskiem których (under whom) z wielką trudnością uczymy się i praktykujemy jakiekolwiek dobro ${ }^{20}$.

18 Kwestię samoistności zła w sposób wyczerpujący przedstawił B. Wolniewicz w książce: Filozofia i wartości II, WFiS UW, Warszawa 1998. Por. tenże, Krytyka teodycei u Bayle'a, w: Filozofia $i$ wartości II, dz. cyt., s. 95-99. Natomiast syntetyczne opracowanie tego samego zagadnienia znajdujemy też u P. Okołowskiego: Między Elzenbergiem a Bierdiajewem, WFiS UW, Warszawa 2012; por. tamże: rozdz. Bierdiajew a Zdziechowski. Spór o sens pesymizmu, s. 228-231.

19 W tym samym duchu pozostają wywody Edwardsa z jego słynnej monografii dotyczącej grzechu pierworodnego, w której autor broni tezy o pogarszaniu się grzeszności będącej skutkiem samego tylko biegu czy porządku natury. Por. tenże, Original Sin, dz. cyt., s. 384-385.

20 Por. J. Edwards, Corruption of Nature, w: tegoż, ,C Controversies” Notebook, ed. Jonathan Edwards Center, Works of J. Edwards Online, Vol. 27. Powyższy tom nie został jeszcze wydany jako osobna książka, tymczasem wersja online, z której korzystaliśmy, wciąż jest w opracowaniu 
Z powyższych słów wynika, że wychowanie ku cnocie moralnej wymaga potężnego wysiłku rodziców i szerszej jeszcze wspólnoty. Przy czym najlepsze nawet metody i najlepsi wychowawcy nie gwarantują sukcesu w tej dziedzinie - a jest nim dopiero szczera miłość wychowanka do dobra moralnego, jako stojącego najwyżej w jego hierarchii wartości, czyli motywów duchowych. Edwards niejednokrotnie w kazaniach zwraca uwagę na fakt, że wielu ludzi dorasta, słuchając Ewangelii, a mimo to ich serca pozostają zatwardziałe. W i a r a tych osób jest powierzchowna. Czytamy: „Zostali wychowani w wierze i przez zwyczaj skłaniają się ku niej, nigdy jednak nie byli przekonani o jej prawdziwości”21.

Jak to ujmuje filozof, dzieje się tak, ponieważ „natura [ludzka - przyp. A. Z.] jest niereceptywna wobec duchowego pojmowania"22. Tę samą tezę powtarza nieco innymi słowy w ujęciu teologicznym. Przyjmuje ona wtedy postać następującą: „Natura ludzka jest przeciwna każdej prawdzie religijnej; sprzeciwia się i stawia opór całemu temu światłu" ${ }^{23}$.

Wspomniana „niereceptywność” nie jest tylko brakiem receptywności, niezdolnością do odbioru tego, co duchowe, swego rodzaju ślepotą czy głuchotą, nie jest jedynie biernym oporem, sprowadzającym się do defensywy. Przeciwnie, jest to opór czynny o charakterze ofensywnym, jest to aktywna antyreceptywność - wrogość wobec moralnego dobra. Przyczyny tej ostatniej Edwards tłumaczy następująco:

i niestety nie posiada numerowanych stron. Co więcej, powyższa notatka, w niniejszym tomie, pozostaje niewidoczna z pozycji jego głównego menu - brak w nim łącza do Part I Original Sin. Aby ją odnaleźć, należy otworzyć Headnote Controversies Hednote i stamtąd wybrać w prawym dolnym rogu link Next section. Rzeczony fragment zaczyna się na wysokości przypisu nr 12. URL: <http://edwards.yale.edu/archive?path=aHR0cDovL2Vkd2FyZHMueWFsZS51ZHUvY2dpLWJpbi9uZXdwaGlsby9n ZXRvYmplY3QucGw/Yy4yNjoyLndqZW8=> (dostęp: 18.11.2017).

${ }_{21}$ Tenże, Warnings of Future Punishment Don't Seem Real to the Wicked, w: tegoż, Sermons and Discourses: 1723-1729, dz. cyt., s. 202. Por. też J. Edwards, Profitable Hearers of the Word, w: tegoż, Sermons and Discourses: 1723-1729, dz. cyt., s. 243, 246-277. Szczególnie krytycznie podchodzi Edwards do hipokryzji niewierzących kapłanów, których uważa za największych szkodników dla wiary. Ich działania porównuje do karykaturalnych ruchów małp, które starają się naśladować człowieka. Por. tenże, Spiritual Understanding Denied to the Unregenerate, w: tegoż, Sermons and Discourses: 1723-1729, dz. cyt., s. 91-92.

22 Por. J. Edwards, Spiritual Understanding Denied to the Unregenerate, dz. cyt., s. 85.

23 Tenże, Warnings of Future Punishment Don't Seem Real to the Wicked, dz. cyt., s. 206. 
Człowiek dąży do $[\ldots]$ celów bez poszanowania Boga [tj. moralnej doskonałości - przyp. A. Z.] i jego prawa. Tymczasem Bóg dalej wymaga tego, co poprzednio, a to rodzi jedynie wrogość w sercu człowieka. Odtąd człowiek prowadzi wojnę z Bogiem ${ }^{24}$.

Dla c złowieka naturalnego, a tym samym zepsutego, bo pozbawionego łaski immanentnej bądź transcendentnej, moralność jest przeszkodą w stosowaniu środków i realizacji celów dla niego atrakcyjnych, a przeciwnych jej samej. Moralność jest przeszkodą dla celów niemoralnych, toteż c złow iek naturalny dąży do jej unicestwienia wszędzie tam, gdzie nie służy ona jego interesowi. Z kolei tam, gdzie może mu się jakoś przysłużyć, jest jedynie quasi-moralnością, moralnością na opak. Nawiązując do Kantowskiej metafory rosochatego drzewa, z którego nic prostego wystrugać się nie da, można powiedzieć, że jest to moralność odbita w krzywym zwierciadle - wszystko, co proste, jawi się w nim jako koślawe.

\section{Rodzaje skłonności w naturze ludzkiej}

Około roku 1727, w jednej ze swych wczesnych notatek dotyczących grzechu pierworodnego, Edwards zauważa niezbyt precyzyjnie i jak gdyby przeciw tezie o istnieniu osobnej skłonności do zła moralnego, że nie trzeba zakładać istnienia niczego nowego poza skło n n o ści a mi naturalnymi, aby thumaczyć niemoralne zachowania człowieka ${ }^{25}$. Swoje stanowisko ujmuje następująco:

Nie ma nic nowego dodanego (put into) do natury, co nazywamy grzechem, poza samą tą miłością własną, która koniecznie należy do natury działającej i oddziałującej bez regulacji ze strony tego nadrzędnego pryncypium [tj. miłości moralnego dobra - przyp. A. Z.]; która prymitywnie należy do naszej natury i jest konieczna dla harmonijnego jej istnienia. Naturalna i konieczna skłonność do nas samych [miłość własna - przyp. A. Z.] pozbawiona tego zarządcy i przewodnika będzie z pewnością, bez pomocy czegokolwiek innego, wytwarzać, a raczej stanie się wszystkimi tymi grzesznymi inklinacjami, które znajdują się w skorumpowanej naturze człowieka ${ }^{26}$.

24 J. Edwards, Original Sin, dz. cyt., s. 383.

25 Tenże, No. 301 Sin and Original Sin, w: tegoż, The „Miscellanies” 1-500, ed. T. A. Schafer, Works of J. Edwards, Vol. 13, Yale University Press, New Haven 1994, s. 387-389.

26 Tamże, s. 387. 
To samo powtarza, a zarazem uzupełnia, polemizując $\mathrm{z}$ arminianinem Johnem Taylorem, w ostatnim wydanym za życia traktacie Grzech pierworodny. Czytamy w nim:

Aby ocenić naturę jako zepsutą, zaiste, by mówić o całkowitej przyrodzonej nieprawości serca ludzkiego nie ma najmniejszej potrzeby zakładać jakiejkolwiek złej jakości wzbudzonej (infused) czy zaszczepionej (implanted), czy to wykutej (wrought) w naturze człowieka przez jakaś p o zy tywną przyczynę, czy jakikolwiek wpływ, czy to Boga, czy stworzenia, albo zakładać, że człowiek został poczęty ze źródłem zła w swoim sercu. Takim, jakim jest cokolwiek właściwie pozytywnego ${ }^{27}$.

W ostatniej wypowiedzi autor wyklucza cztery możliwości. Po pierwsze, że w naturze ludzkiej pod wpływem bezpośredniego oddziaływania Boga czy człowieka budzi się uśpione wcześniej zło. Po drugie, że sam Bóg, bezpośrednio, stwarza nieobecną wcześniej pobudkę do zła moralnego. Po trzecie, że nieobecna pobudka do zła powstaje w wyniku tresury czy wychowania. Po czwarte, że zła pobudka istniała czy też istnieje aktywnie w naturze od samego początku.

Powyższa wypowiedź Edwardsa jest przewrotna, gdyż wbrew pozorom nie przeczy łasce immanentnej - wrodzonym moralnym predyspozycjom. Uwzględniając wypowiedzi filozofa dotyczące rozumu, możemy stwierdzić jedynie tyle, że przed jego „obudzeniem”28 nie może istnieć w naturze dyspozycja (aktywna skłonność) do zła moralnego jako takiego. Edwards nie neguje wszak możliwości samorzutnego aktywowania się pozytywnego źródła, czy też skłonności do zła moralnego w sercu człowieka pod wpływem nieobecności w naturze skłonności do moralnego dobra (w momencie „przebudzenia” rozumu). Wrócimy do tej kwestii, gdy odpowiemy na pytanie: jak rozumieć należy skłonności naturalne? Wspominaliśmy już o c złowi eku naturalny m, który pozbawiony jest pozytywnego stosunku do moralności. Przydomek „naturalny" odnosi się do niego ze względu na skłonnoś ci naturaln e, którymi się kieruje. Otóż nie są one u Edwardsa tożsame z popęda-

\footnotetext{
27 J. Edwards, Original Sin, dz. cyt., s. 380-381.

28 W świetle współczesnej wiedzy na temat antropogenezy i pradziejów człowieka gatunek nasz istnieje około dwieście tysięcy lat i obywał się długo bez rozumu (żyjąc w hordzie), zanim - wraz z językiem - został on aktywowany.
} 
mi, tak jak je dziś pojmujemy. Zasadniczo są to wszystkie dyspozycje składające się na o s obę, a mówiąc precyzyjniej - na u s p o s ob i e n i e w sensie Wolniewiczowskim ${ }^{29}$, rozumiane jako składowe czynne (sprężyny działania), czyli ogół dyspozycji emocjonalnych tejże osoby. Poza popędami należą do nich również składowe charakterologiczne takie jak: egoizm, altruizm, współczucie, wdzięczność, ale także złośliwość i zawiść. Wszystkie wyżej wymienione skłonni jesteśmy uznawać dzisiaj za pobudki duchowe. Ten ostatni termin Edwards rezerwuje jednak wyłącznie dla motywów moralnych działania. Toteż w Naturze prawdziwej cnoty klasyfikuje wszystkie dy s p o z y c j e naturalne, które nazywa również instynktami, podług dwóch osi podziału. Pierwsza dzieli d y s pozycje naturalne na osobowe (personal) i społeczne (social). Te pierwsze, jak stwierdza, ,respektują tylko nas samych osobiście”. Jak sądzimy, należy to rozumieć tak, że bezpośrednio dotyczą jedynie nas, oraz że do ich realizacji nie jest konieczna obecność drugiego człowieka. Są też bardziej pierwotne, gdyż w toku osobniczego i gatunkowego rozwoju pojawiają się wcześniej niż społeczne. Istnieją po to, by zapewnić indywidualne trwanie i komfort. Jako przykład Edwards podaje zaspokajanie głodu czy pragnienia. Z kolei te drugie, społeczne - ,rozciągają się na innych". A zatem do ich realizacji potrzebna jest druga osoba, nie dotyczą bezpośrednio jedynie nas samych. Można też powiedzieć, że warunkiem istnienia tych skłonności, jest istnienie innych ludzi. Edwards stwierdza wprost, że służą one trwaniu gatunku i społeczeństwa ${ }^{30}$. Przykładem takowych skłonności są wzajemne zmysłowe inklinacje między płciami.

Zauważmy, że oba przykłady należą do kategorii potrzeb zmysłowych, służących bezpośrednio biologicznemu trwaniu jednostki i gatunku, jednak powyższy podział nie odnosi się tylko do nich. Jest druga oś podziału dyspozycji naturalnych: obok dyspozycji zewnętrznych i zmy$\mathrm{s} \nmid \mathrm{ow} \mathrm{y} \mathrm{h}$ (external and sensitive), którym odpowiadają potrzeby bio-

\footnotetext{
29 Por. B. Wolniewicz, Hedonizm i obowiązek, w: tegoż, Filozofia i wartości IV, Wydawnictwa Uniwersytetu Warszawskiego, Warszawa 2016, s. 119 oraz tenże, Polemika Kanta z hedonizmem, w: tegoż, Filozofia $i$ wartości IV, dz. cyt., s. 140.

30 Por. J. Edwards, Chapter VI On Particular Instincts of Nature Which in Some Respects Resemble Virtue, w: tegoż, The Nature of True Virtue, w: tegoż, Ethical Writings, dz. cyt., s. 600, 612.
} 
logiczne, wyróżnia Edwards także we w nętrzne i mentalne (internal and mental), którym odpowiadają potrzeby psychiczne czy mówiąc precyzyjniej: charakterologiczne ${ }^{31}$. Można więc podać także przykłady dyspozycji osobowych i społecznych o charakterze mentalnym. Właśnie te dwa typy dyspozycji składają się na m iło ść w wa s n ą w sensie szerokim. Skłonności społeczno-mentalne to, jak stwierdza Edwards, p o ruszenia umysłu (affections of mind) wobec „niektórych bratnich stworzeń” (tj. ludzi, w oryg. fellow creatures), ,a w pewnych przypadkach wobec ludzi w ogóle". Owe poruszenia mogą być życzliwe bądź nie. Jako przykłady autor podaje współczucie, gniewliwość, niewdzięczność, wzajemne więzi rodziców i dzieci lub zazdrość małżeńską. Upraszczając, można więc powiedzieć, że w kategorii tej mieści się zarówno miłość do osób konkretnych (Edwardsowska „miłość z zadowolenia”), ale także, jak można wnosić z wcześniejszych a także późniejszych wypowiedzi autora, nienazwana wprost miłość spraw (wartości) intersubiektywnych, wspólnotowych (Edwardsowska „miłość z dobroczynności”; której przykładem jest miłość do kraju, tj. patriotyzm).

Co znaczące, autor nie podaje jedynie przykładu pobudki osobowomentalnej. Wiemy wszak, zgodnie $z$ jego własnymi słowami, że poruszenia naturalne zawdzięczamy instynktowi bądź miłości własnej, a poruszenia wywodzące się z tej ostatniej, jako zależne od praw natury ( $\mathrm{tj}$. pojawiające się w sposób konieczny prędzej lub później, za sprawą miłości własnej), mogą być również zaliczane do powstających z instynktu (w sensie Edwardsowskim) ${ }^{32}$. Wnosimy stąd, że odpowiednikiem pobudki osobowo-mentalnej jest po prostu miłość własna w sensie ścisłym, w jej przejawie czy interesie najbardziej bezpośrednim, a zatem chcenie swojego dobra o charakterze ewidentnie autocentrycznym (dążenie do tego, by czuć się dobrze ze sobą, by realizować i afirmować siebie), w opozycji do heterocentrycznego „egoizmu grupowego”. Do przykładów skłonności autocentrycznych pochodzących z miłości własnej, pojawiających się we wcześniejszym rozdziale Natury prawdziwej cnoty, należą honor,

31 Por. tamże, s. 600.

32 Por. tamże, s. 601. 
duma czy chęć zdobycia poklasku lub zaszczytów ${ }^{33}$. Istniałyby zatem pobudki mentalne dwojakiego typu: osobowo-mentalne oraz s połeczno-mentalne. Wymienione podziały obrazuje poniższa tabela.

\begin{tabular}{|c|c|c|}
\hline $\begin{array}{c}\text { SKLONNOŚCI } \\
\text { NATURALNE }\end{array}$ & $\begin{array}{c}\text { OSOBOWE } \\
\text { (personal) }\end{array}$ & $\begin{array}{c}\text { SPOLECZNE } \\
\text { (social) }\end{array}$ \\
\hline $\begin{array}{c}\text { ZMYSLOWE } \\
\text { (external } \\
\text { and sensitive) }\end{array}$ & $\begin{array}{c}\text { INTERES } \\
\text { skłonności płynące z ogółu } \\
\text { odczuwanych potrzeb } \\
\text { biologicznych, przejawia- } \\
\text { jące się jako indywidualne } \\
\text { egoizm i altruizm }\end{array}$ & Skłonności płciowe \\
\hline $\begin{array}{c}\text { MENTALNE } \\
\text { (internal and mental) }\end{array}$ & $\begin{array}{c}\text { Miłość własna } \\
\text { (skłonności } \\
\text { autocentryczne) }\end{array}$ & $\begin{array}{c}\text { PORUSZENIA DUSZY } \\
\text { (affections of mind): } \\
\text { miłość do bratnich dusz + } \\
\text { miłość do spraw (wartości) } \\
\text { grupowych (egoizm } \\
\text { i altruizm grupowy) }\end{array}$ \\
& & SPOLECZNE \\
\hline
\end{tabular}

Tabela 1: Edwardsowski podziat dyspozycji (do działań) naturalnych podmiotu - ze względu na kierunek woli: skłonności osobowe sa tu rozumiane jako wsobne, do siebie skierowane, a spoteczne - na innych, na zewnatrz.

Edwardsowski człowiek naturalny to synonim biblijnego człowieka cielesnego. Ten, zdaniem Edwardsa, w swym działaniu kieruje się wyłącznie pobudkami należącymi do tych czterech wymienionych już kategorii: osobowo-zmysłowych, społeczno-zmysłowych, osobowo-mentalnych i społeczno-mentalnych. Natomiast wcale

33 Por. J. Edwards, Chapter IV Of Self-Love and Its Various Influence to Cause Love to Others or the Contrary, w: tegoż, The Nature of True Virtue, dz. cyt., s. 577. 
nie kieruje się obiektywnymi pobudkami duchowymi (moralnymi), lecz jedynie intersubiektywnymi wartościami życiowymi (sprzyjającymi przetrwaniu i dobrobytowi jego oraz jego wspólnoty). Człowiek taki może, co najwyżej, stwarzać pozory kierowania się cnotliwymi pobudkami. Iluzja taka, jak stwierdza autor traktatu, zasadniczo tworzy się na gruncie skłonności społeczno-mentalnych, a nie na bazie osobowo-mentalnych. Pisze Edwards:

Im większa liczba ludzi, na których rozszerza się prywatne uczucie, tym bardziej ludzie są skorzy [...] mylić je z prawdziwą cnotą, gdyż prywatny system ma wtedy pozór uniwersalnego [...]. Jest to powód, dla którego miłość własna wcale nie jest mylona z prawdziwą cnotą, bo choć jest w niej coś z natury cnoty, to jest miłość i dobra wola [czyt. „dobroczynność” - przyp. A. Z.], to jednak obiekt jej jest na tyle partykularny (private), a zakres tak wąski, że żadnym sposobem nie monopolizuje perspektywy, o ile nie stanie się to z winy samej osoby, która z powodu wielkości swojej dumy nie zacznie sobie wyobrażać, że jest wszystkim ${ }^{34}$.

Trudno pomylić cnotę $\mathrm{z}$ autocentryczną skłonnością do dumy. Natomiast o skłonnościach społeczno-mentalnych, jako grupowych i heterocentrycznych, można powiedzieć, że stanowią wyraz „egoizmu” lub „interesu grupowego”, chociaż bywa, iż stoi on w sprzeczności z indywidualnym egoizmem lub interesem. Jednostka powodowana skłonnościami sprzecznymi z jej indywidualnym interesem, ale zgodnymi z interesem grupy postępuje w tym sensie bezinteresownie, ,altruistycznie” (choć nie zawsze w zgodzie z moralnym osądem), stąd jej czyn bywa mylony z czynem cnotliwym. Edwards stwierdza, że defekt tych skłonności polega na ich prywatnej [tj. partykularnej - przyp. A. Z.] naturze ${ }^{35}$.

Kryterium odróżniającym skłonności osobowe od społecznych w przedstawionej wyżej tabeli jest kierunek woli. Gdyby jednak przeprowadzić podział według źródeł dyspozycji (czego autor traktatu nie czyni), klasyfikacja przedstawiać się będzie nieco inaczej. Poniższa tabela rów-

34 Por. tenże, Chapter VII. The Reason Why Those Things That Have Been Mentioned, Which Have Not the Essence of Virtue, Have Yet by Many Been Mistaken for True Virtue, w: tegoż, The Nature of True Virtue, dz. cyt., s. 611.

35 Por. tamże, s. 610. 
Jonathan Edwards o negatywnej i pozytywnej przyczynie zła moralnego...

nież odzwierciedla poglądy Edwardsa, pozwalając lepiej zrozumieć na czym, według niego, polega zepsucie natury ludzkiej.

\begin{tabular}{|c|c|c|}
\hline $\begin{array}{l}\text { SKLONNOŚCI } \\
\text { NATURALNE }\end{array}$ & $\begin{array}{c}\text { OSOBOWE } \\
\text { (personal) }\end{array}$ & $\begin{array}{c}\text { SPOLECZNE } \\
\text { (social) }\end{array}$ \\
\hline $\begin{array}{l}\text { ZMYSLOWE } \\
\text { (external } \\
\text { and sensitive) }\end{array}$ & $\begin{array}{c}\text { INTERES } \\
\text { skłonności płynące z ogółu } \\
\text { odczuwanych potrzeb bio- } \\
\text { logicznych, przejawiające } \\
\text { się jako indywid. egoizm } \\
\text { i altruizm } \\
\text { (w tym także płciowe) }\end{array}$ & $\varnothing$ \\
\hline $\begin{array}{c}\text { MENTALNE } \\
\text { (internal and mental) }\end{array}$ & $\begin{array}{l}\text { Miłość własna (self love) } \\
\text { = CHARAKTER } \\
\text { (rozumiany jako } \\
\text { ostateczny arbiter woli) }\end{array}$ & $\begin{array}{c}\text { SPOŁECZNE } \\
\text { PORUSZENIA DUSZY } \\
\text { (affections of mind): } \\
\\
\text { miłość do bratnich dusz + } \\
\text { miłość do spraw (wartości) } \\
\text { grupowych (egoizm } \\
\text { i altruizm grupowy) }\end{array}$ \\
\hline
\end{tabular}

Tabela 2: Edwardsowski podziat dyspozycji (do działań) naturalnych podmiotu - ze względu na ich źródło: osobowe tkwiq w samej duszy, a spoleczne sa heterogeniczne, biora się i z duszy, i od wspólnoty.

Wszystkie skłonności zmysłowe mają swe źródło w osobie. Ich istnienie czy aktywacja nie jest w żaden sposób zależna od społecznego wpływu. Inaczej z pobudkami charakteru. Miłość włas na ma źródło w osobie, włącznie ze złośliwością, która jest jej częścią. Miło ś ć wła s n a aktywuje się spontanicznie, bez udziału społeczeństwa. Jedna ze składowych tak rozumianego charakteru (łaska immanentna) wymaga jednak wspólnoty (łaski transcendentnej) jako warunku koniecznego do jej aktywacji. Taka predyspozycja może się wówczas zmienić w s kło n - 
ność d u c how ą. Skłonnością tą jest miłość moralnej cnoty (inaczej miłość do Boga), która przejawia się w dwójnasób - realizując dobro: jako miłość do konkretnej osoby (ze względu na jej moralną dobroć i tylko ze względu na nią; to czysta miłość z zadowolenia), oraz jako miłość do spraw czy wartości (to czysta miłość z dobroczynności).

O odróżnieniu pobudek naturalnych i duchowych czytamy w Grzechu pierworodnym. Mowa tam o dwóch rodzajach pryncypiów: poślednich (inferior), które nazywane są też naturalnymi, i nadrzędnych (superior) - określanych tam także jako duchowe czy ponadnaturalne (supernatural). Autor pisze o nich (w przypisie) rzecz następującą:

Niech czytelnik zwróci uwagę w jakim sensie używam słów „naturalne” i ,ponadnaturalne" (supernatural); nie jako rozróżnienie między tym, co jest współstworzone (concreated) czy przyrodzone (connate), a tym, co zostało w sposób nadzwyczajny wprowadzone potem, poza początkowym stanem rzeczy czy oryginalnie ustalonym porządkiem, zaczynającym się wraz z początkiem natury ludzkiej; ale jako odróżnienie tego, co przynależy do czy wypływa $\underline{z}$ tej natury jaką człowiek posiada jedynie jako człowiek i tych rzeczy, które są czymś p o n ad to [pierwsze - przyp. A. Z.]; dzięki czemu człowiek nazywany jest nie tylko c złow i e k i e m, ale prawdziwie ś wi ę t y m, c n ot liwy m i duchowy m człowiekiem; które choć miały swój początek w Adamie, jednocześnie z początkiem ludzkości, i choć są niezbędne dla perfekcji i dobrobytu ludzkiej natury, nie są jednak istotne dla jej ukonstytuowania, czy konieczne dla jej istnienia, w takiej mierze, że ktoś może mieć wszystko, co potrzebne do bycia człowiekiem wyłączywszy te ostatnie ${ }^{36}$.

Opozycja, którą posługuje się Edwards, nie jest więc opozycją między tym, co wrodzone i nabyte, ale opozycją między tym, co życiowe czy biologiczne, amoralne i antyduchowe a tym, co duchowe czy moralne. Jest przeciwieństwem tego, co wypływa z natury spontanicznie, i tego, co wymaga wysiłku wspólnoty. Owe skło n n o ś c i n a t u raln e, choć antagonistyczne względem skłonności moralnych, zasadniczo są jednak, zdaniem filozofa, moralnie indyferentne. Oznacza to, że zachowania, które rozumna istota ocenia jako moralne lub niemoralne, a podyktowane przez skłonności naturalne, stanowią jedynie środki do celu innego

36 Tamże, s. 381. Podkr. A. Z. 
niż to, co z nich bezpośrednio w postaci dobra lub zła moralnego wynika. Celem tym jest zawsze zaspokojenie jakiejś p otrze by naturalnej. Innymi słowy, motywem owych zachowań nie jest ani dobro moralne, ani zło moralne. Same te s kłonn oś c i naturalne, jak autor stwierdza, są konieczne dla istnienia człowieka i jako takie są pożyteczne, niezbędne i nieusuwalne ${ }^{37}$. Nie są to więc skłonności do zła moralnego. To uzasadnia i rozjaśnia twierdzenie o wyjściowym czy początkowym braku pozytywnego źródła zła moralnego w naturze ludzkiej. Niemniej jednak wskutek nieobecności gotowych dyspozycji moralnych i przebudzenia rozumu pobudki naturalne przedzierzgają się w pobudki niemoralne zmienia się ich charakter, tym samym stają się pozytywnym źródłem zła. Każda z nich, u istot obdarzonych rozumem, zaczyna w sposób świadomy służyć złu moralnemu. W wyniku czego de facto budzi się w człowieku coś nowego, czego wcześniej (w okresie przedjęzykowym) w nim nie było i być nie mogło, gdyż wcześniej nie operował on kategorią dobra i zła moralnego. Wspomnianą nowością jest opór wobec dobra moralnego - pozytywna skłonność do zła moralnego (obiektu równie samoistnego jak dobro moralne), a nie jedynie do zła moralnego jako środka służącego osiągnięciu naturalnego celu. Interpretując słowa Edwardsa, można więc powiedzieć, że dyspozycja do niemoralnych zachowań budzi się nie w wyniku dodania czegokolwiek do rozumnej natury ludzkiej, ani nawet nie w wyniku działania wspólnoty, lecz w wyniku nieobecności w tejże naturze miłości dobra moralnego oraz braku wspólnotowych działań hamujących złe zapędy. Innymi słowy: skłonność do zła budzi się w wyniku zepsucia natury ludzkiej, a mówiąc już całkiem zwyczajnie: w wyniku nieobecności w niej dyspozycji do dobra moralnego i nietrzymania tej natury w ryzach. O n a t u r a l n e j genezie zła czytamy w Grzechu pierworodnym. Autor dzieła przytacza poglądy oponenta, a następnie wykłada swoje stanowisko. Czyni to następująco:

Taylor odrzuca całkowicie przekonanie, że bieg natury jest właściwą, aktywną przyczyną, która działa sama z siebie, bez Boga jeśli ten tylko na to pozwoli $[\ldots]^{38}$.

37 Por. J. Edwards, The Nature of True Virtue, dz. cyt., s. 600, 612.

38 Tenże, Original Sin, dz. cyt., s. 384. 
To, że potomstwo Adama rodzi się bez świętości, a zatem ze zdeprawowaną naturą, że jest to skutkiem ustal on e go bi e gu natury, jest tak samo oczywiste jak to, że to bieg natury jest przyczyną kontynuacji złych działań w przypadku pojedynczej osoby ${ }^{39}$.

Ze słów Edwardsa wynika, że sam porządek natury, czy też prawo natury, które ustanowił Bóg, prowadzi - na skutek braku łaski - do powstania skłonności przeciwnych dobru moralnemu.

\section{Podsumowanie}

Edwards stwierdza jednoznacznie - zarówno w swych wczesnych, jak i późnych tekstach - że człowiek potrafi się świadomie cieszyć popełnianym złem i że stoi za tym pozytyw na przyczyna działania, innymi słowy: wrodzona w naturę skłonność - miłość w ł a s n a. Około roku 1731, uzasadniając istnienie złej radości w naturze ludzkiej, autor notuje:

Sama miłość własna, jeśli jest jedynym zarządzającym pryncypium w sercu i brak jej okiełznania, będzie skłaniać do rozkoszowania się cudzym nieszczęściem: ponieważ miłość własna szuka swojego własnego porównywalnego [z cudzym - przyp. A. Z.] szczęścia i chce pomniejszać swoje własne porównywalne nieszczęście, co jest uzyskiwane poprzez pogrążanie innych. Właśnie to wydaje się powodem, dla którego diabły rozkoszują się cudzym nieszczęściem.

Miłość własna będzie rozkoszować się okrucieństwem i wystawianiem innych na cierpienie, gdyż jawi się to jej, jako posiadanie mocy i dominacji. Moc jednego nad drugim jawi się w byciu zdolnym (being able) do dręczenia tego drugiego, co pokazuje, że znajduje się on w jego mocy. Ponieważ wszyscy poważają swój własny komfort i własne szczęście i nie rozstaliby się z nimi, gdyby byli wolni; i im więcej jeden jest dręczony przez drugiego, tym bardziej widać, że znajduje się w mocy drugiego, gdyż jest to większa podnieta dla dręczonego, by pokazać swoją wolność, gdyby ją miał, aby wybawić samego siebie ${ }^{40}$.

Jak widać, autor umieszcza złą wolę - czy też: złośliwość, a zatem chcenie cudzego zła i rozkoszowanie się nim oraz zawiść, a więc nie-

\footnotetext{
39 Tamże, s. 385.

40 J. Edwards, No. 534 Restraining Grace and Corruption of Man's Nature, w: tegoż, The „Miscellanies" 501-832, ed. by Ava Chamberlain, Works of J. Edwards, Vol. 18, Yale University Press, New Haven 2000, s. 78.
} 
chcenie cudzego dobra - pośród składowych wrodzonej, n a t u r a ln e j miło śc i wła s n ej. Z jego słów wynika, że zła wola jest człowiekowi wrodzona jako skłonność, chociaż w sposób ne gaty w ny; jest skutkiem braku przyrodzonej skłonności do dobra, gdyż nic wrodzonego jej jako takiej nie hamuje, a pozyty wnie stanowi skutek koniecznej dla natury człowieka m iło śc i wła s n e j, która jest moralnie indyferentna i skupiona na własnych zachciankach, tudzież przyjemnościach i korzyściach.

Wspominana niejednokrotnie przez Edwardsa złośliwość (malice), zawistny duch (envious spirit), dyspozycja diabła (disposition of the devil) czy dyspozycja piekła (disposition of hell) ${ }^{41}$, bo to ona właśnie odpowiada za radość ze zła, choć jako skłonność powstaje spontanicznie na bazie miłości własnej, to jednak, naszym zdaniem, podobnie do miłoś c i do b ra mora ln e g o jest skłonnością osobną i równie n i e n a t u ra ln ą, co tamta. Jest niezależna od zwierzęcego egoizmu w tym znaczeniu, że stanowi pobudkę zw i e r z chni ą, czy też: sterującą, jako że wypełnia miłość własną odrębną treścią, czym wpływa na jej formę i kierunek. Nie znaczy to, że jest pobudką duchową w sensie Edwardsowskim (tj. cnotą). Autor Natury prawdziwej cnoty powiedziałby, że jest to pobudka an ty d u c how a, gdyż polega na nienawiści do dobra. Tej ostatniej nie znajdziemy w świecie zwierząt. Tak ,nieludzka” pobudka pojawić się może jedynie w świecie ludzi i Edwards ma tego świadomość, gdy w traktacie o Grzechu pierworodnym, stwierdza, że ludzie są znacznie gorsi od dzikich bestii ${ }^{42}$. (Cytowaliśmy już tę wypowiedź we wcześniejszym artykule, poświęconym kwestii zła w naturze ludzkiej ${ }^{43}$ ). W jednym z kazań z okresu 1723-1729 autor powiada o owej diabelskiej skłonności dobitnie:

Wielu było okrutnych tyranów i krwawych prześladowców, którzy rozkoszowali się niczym innym, jak tylko mordowaniem i okrutnym męczeniem ludzi; którzy doprowadzili wiele tysięcy prawych i sprawiedliwych ludzi do śmierci tylko dlatego, że byli oni prawi i cnotliwi; palili ich na ruszcie, skó-

\footnotetext{
${ }^{41}$ Por. tenże, Sermon Five:Charity Contrary to an Envious Spirit, w: tegoż, Charity and its Fruits, dz. cyt, s. 230-231.

42 Por. tenże, Original Sin, dz. cyt, s. 168.

43 Por. A. Zalewska, Zto radykalne w naturze ludzkiej wedtug Jonathana Edwardsa, dz. cyt., s. 127-147.
} 
rowali żywcem, biczowali do śmierci, zaprzęgali cały swój dowcip do pracy, by wynaleźć najokrutniejsze sposoby dręczenia; czasem nie ustawali w przedłużaniu ich mąk do trzech lub czterech dni, nim umarli, tak aby wycierpieli jak najwięcej nieszczęścia; i postępowali tak ze wszystkimi, bez względu na płeć czy wiek; męczyli mężczyzn i kobiety; brali małe dzieci i piekli je na oczach ich matek ${ }^{44}$.

Jeśli morduje się kogoś tylko dlatego, że jest cnotliwym człowiekiem, trzeba czuć nienawiść wobec samej cnoty. Człowiek jako istota zdolna do rozpoznania moralnego zła staje się zdolny do cieszenia się nim jako takim. Stanowi ono dodatkową podnietę do działania. Nie wystarczy przecież kochać samego siebie, aby kochać spożywanie małży, tj. aby ich spożycie dostarczało nam szczególnej delektacji. Trzeba też kochać smak małży, a nie każdy człowiek go kocha, choć każdy na pewno rozumie, że w sytuacji skrajnego wygłodzenia, spożycie tego mięczaka uratuje mu życie ${ }^{45}$. Identycznie ze smakiem zła.

Studiując zarówno wczesne, jak i późne pisma Edwardsa, można odnieść wrażenie, że zasadnicze poglądy na kwestie dobra i zła moralnego, woli oraz rozumu uformowały się w umyśle filozofa już we wczesnej młodości, między końcem drugiej dekady życia a początkiem trzeciej, kiedy to Edwards przechodził kryzys wiary związany z analizą kwestii predestynacji i teodycei. Wtedy to filozof wypracował zasadnicze intelektualne rozwiązania, które dopracowywał przez resztę życia. Od początku działalności Edwards niezmiennie trwał przy tezie o n a t u ra lis t y c z n o-autocentrycznym charakterze pobudki do moralnego zła jakim jest sama miłość włas na. Jak wynika z analizy jego pism, koncepcja ta sprowadza się zasadniczo do twierdzenia, że zło moralne może wypływać z każdej pobudki naturalnej z osobna, jak i z wielu takich pobudek łącznie. Niezależnie od tego, i jak gdyby wbrew tezie o neutralności moralnej p obudek naturaln y c h, wyróżnioną pozycję wśród

\footnotetext{
${ }_{44}$ J. Edwards, Warnings of Future Punishment Don't Seem Real to the Wicked, dz. cyt., s. 209. Podkr. A. Z.

45 Niektórzy będą kontrargumentować, że w sytuacji skrajnego głodu, na przykład takiego, jaki miał miejsce na Ukrainie w latach 1932-1933, wszystko człowiekowi smakuje. Otóż nie wszystko mu smakuje, ale gotowy jest pożreć cokolwiek (choćby ciała zmarłych), tak, że zdaje się nie czuć nawet smaku tego, co pożera.
} 
nich zajmuje, według Edwardsa, złośliwość (chcenie cudzego zła) wraz ze swym rewersem, zawiścią (niechcenie cudzego dobra), jako potężne g e neratory złej woli. Przyczyną takiego stanowiska, jak sądzimy, był wzgląd na praktyczną potrzebę rozwiązania teodycei w związku z jej znaczeniem pedagogicznym.

Stwierdzenie, że źródło zła w naturze ludzkiej jest zasadniczo neutralne moralnie i konieczne dla jej istnienia, stanowi sensowne uzasadnienie dla stworzenia człowieka takim właśnie, jakim jest, wyposażonego w skłonność, która przynosi niekiedy niemoralne skutki. Nie tłumaczy ono natomiast decyzji Stwórcy o użyczeniu istnienia zarówno tym, którzy łaskę otrzymają, jak i tym, którzy z pewnością jej nie otrzymają. Po co stwarzać zarówno złych, jak i dobrych? Należałoby odpowiedzieć następująco: widocznie jest to w porządku rzeczy konieczne. Dlaczego Bóg dopuszcza istnienie zła naturalnego i moralnego? Edwards odpowiada jak każdy chrześcijański duchowny - że jest to Boża tajemnica, ale na pewno nie stoją za nią złe intencje Stwórcy. A zatem, bez obawy o uszczerbek dla teodycei, można stwierdzić wprost, zgodnie z tezą tłumaczącą zarówno przewagę zła moralnego, jak i radość z niego, że w naturze istnieje osobna skłonność odpowiadająca za oba stany rzeczy. A jednak Edwards pozostawał w tej materii w sprzeczności ze sobą. Pomijał kwestię, że dla teodycei nie ma znaczenia, czy jest tak, że Bóg wycofuje miłość dobra moralnego, a wskutek tego miłość własna niezbędna do przetrwania i do bycia człowiekiem zaczyna się cieszyć z moralnego zła, de facto stając się miłością do zła (z braku hamulca dla złej radości), czy też Bóg stwarza od razu gotową miłość moralnego zła, która tkwi w naturze człowieka od początku i mogłaby być z tego samego powodu co miłość włas na konieczna dla jej istnienia ${ }^{46}$. Zapewne Edwards uznał, że wierni sprawy nie zrozumieją i z powodów pe d a g o g i c z n y c h stosował tę samą od, z górą, dwóch tysięcy lat strategię duchowieństwa na odwrócenie uwagi wiernych od kwestii, których nie są w stanie pojąć, w związku z czym

\footnotetext{
46 Różnica między jednym i drugim wyjaśnieniem dotyczy jedynie tego, czy Bóg stwarza złą w sensie moralnym pobudkę (taką, która prowadzi do niemoralnych zachowań) od razu czy stopniowo, co dla teodycei nie ma znaczenia, choć może mieć istotną wartość poznawczą pod innymi względami. Natomiast to, że niemoralna pobudka może być konieczna dla istnienia i w tym sensie dobra dla niego, nie czyni jej pobudką moralną, choć uzasadnia jej istnienie.
} 
mogliby niesłusznie odwrócić się od wiary i popaść w moralne upodlenie. Zadaniem duchownego jest przekazanie ogólnego sensu Słowa Bożego, tak aby wierny mógł go pochwycić, aby doszedł do tych samych wniosków praktycznych, choć być może nigdy nie będzie w stanie zrozumieć, jak się sprawy mają rzeczywiście. W tym celu musi posługiwać się uproszczeniami, Witt ge n s te i n o w s ką d rabi ną, którą po osiągnięciu celu należy odrzucić. Podobnie postępują popularyzatorzy skomplikowanych naukowych teorii z dziedziny fizyki, biologii i chemii, którzy potwierdzają, że zasadniczo to, co mówią do niewtajemniczonych, jest fałszem, że nic nie ma się dokładnie tak, jak im to przedstawiają. Niemniej jednak ów fałsz przybliża maluczkim ogólny sens tego, co naukowcy widzą i rozumieją w pełni lub znacznie pełniej.

Niezależnie od kwestii teodycei i potencjalnego istnienia pozytywnej pobudki do zła moralnego oraz powiązanych z nią problemów wychowawczo-moralizatorskich musiał mieć Edwards na względzie niewątpliwy walor pedagogiczny, jaki płynie z prywatywnej koncepcji braku dobra jako braku wrodzonych skłonności moralnych. Koncepcja ta wskazuje bowiem na absolutną konieczność moralnie dobrej wspólnoty dla możliwości ukształtowania jednostek nieautocentrycznych, a zatem takich, które nie kierują się jedynie pobudkami naturalnymi: egoizmem, współczuciem czy złośliwością, ale jednostek o skłonności prawdziwie heterocentrycznej i nakierowanej na moralne dobro. Tylko takie osoby, poprzez dążenie do moralnego dobra, dążą też rzeczywiście do dobra bliźnich i tylko wspólnota, która najwyżej ceni dobro moralne, jest wspólnotą rzeczywiście dobrą. Cel bowiem, który spaja ludzi jest w niej rzeczywiście wspólny, a zysk jednego członka wspólnoty jest rzeczywistym zyskiem dla każdego jej członka z osobna i wszystkich razem. Dobro moralne łączy, a zło dzieli, jak mówił św. Augustyn - jest to druga odsłona asymetrii między tymi dwoma. Nie ma wspólnoty tam, gdzie rzekomi jej członkowie mają na względzie tylko autocentryczne cele, a zatem każdy swoje indywidualne. Ale nie ma i dobrej wspólnoty, gdzie cele są chybione albo szalbierskie. Pierwotne zło w człowieku może okiełznać jedynie dobra wspólnota, to jest taka, która rzeczywiście miłuje głoszone przez siebie 
wartości, a te zostały przez nią właściwie rozpoznane. W ten sposób Edwards postrzegał zbór kalwiński.

\section{Summary}

This article is a voice in the debate on the supposed change of the Edwardian stance on the question of the ontological status of a disposition to moral evil in human nature. According to a common interpretation the young philosopher had upheld a privative standpoint on the matter however, as an adult Edwards claimed the opposite, Paulinistic view. The author of the paper proves this opinion to be false to the philosopher's concept. It is evident that since his earliest notes Edwards has agreed with both these explanations, treated by him as two aspects of the same corruption, and did not change his mind through his lifetime. On the one hand, Edwards thinks that the deprivation of a human heart consists in the want of moral good, that is a lack of moral restraints and active disposition to moral good, which is a negative cause of evil. On the other hand, he is sure that it is positively or effectually caused by morally indifferent natural self love together with malevolence as its part. This means for Edwards that even natural social dispositions like love of persons (Edwardean love of complacence), and love of intersubjective values and matters (Edwardean love of benevolence), naturally come from private interest. Although these dispositions are often mistaken with true virtue, they are morally indifferent too, and can cause evil actions turning into evil dispositions. Only a community focused on the moral good can suppress the latter.

Key words: human nature, natural dispositions, self love, moral evil, malevolence, benevolence, virtue, saving grace. 
